Romani in Britain 



\title{
Romani in Britain
}

The Afterlife of a Language

\author{
YARON MATRAS
}

EDINBURGH UNIVERSITY PRESS 
(C) Yaron Matras, 2010

Edinburgh University Press Ltd

22 George Square, Edinburgh

www.euppublishing.com

Typeset in 10/12 Times New Roman

by Servis Filmsetting Ltd, Stockport, Cheshire, and

printed and bound in Great Britain by

CPI Antony Rowe, Chippenham and Eastbourne

A CIP record for this book is available from the British Library

ISBN 9780748639045 (hardback)

The right of Yaron Matras

to be identified as author of this work

has been asserted in accordance with

the Copyright, Designs and Patents Act 1988. 